\title{
Descriptive Study of Colorectal Cancer in Iraq, 1999-2016
}

\author{
Dr. Taha HT Al-Saigh ${ }^{a}$, Dr. Shahbaa A Al-Bayati ${ }^{b}$, Dr. Shatha A Abdulmawjood ${ }^{c}$, Prof. Dr. Faris A Ahmed ${ }^{d}$ \\ ${ }^{a}$ Department of Surgery, ${ }^{b}$ Department of Physiology, ${ }^{c}$ Department of Medicine, College of Medicine, University of Nineveh,

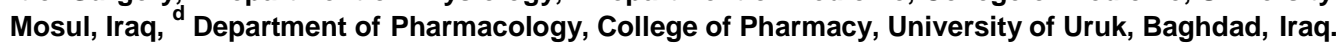 \\ Correspondence: Faris A Ahmed. faris_mawjood@yahoo.com.
}

(Ann Coll Med Mosul 2019; 41 (1):81-85).

Received: $16^{\text {th }}$ Apr. 2019; Accepted: $16^{\text {th }}$ Jun. 2019.

\section{ABSTRACT}

Background: Colorectal cancer has increased in the last decades, which constitutes about $10 \%$ of cancer mortality. It becomes the second and third most common cancer in women and men respectively.

Objective: To explore the factors for colorectal cancer in Iraq including age, gender, family history, diabetes, smoking, serum carcinembryonic antigen (CEA) as a predictor factor, stages of cancer, bowl habit, and symptoms.

Patients and methods: This study was conducted in surgical unit at Alkathymia Teaching Hospital, Baghdad and in Al-Jammhory Teaching Hospital, Mosul, during the period from Feb-1999 to June-2016. This is a case series study for 956 patients with colorectal cancer. The data gathered included: age, gender, family history, diabetes and smoking, serum CEA, stages of the disease, bowl habit and symptoms. Data are presented as mean and percentage, and were analyzed by using Chi square goodness of fit test. $p$ values $\leq$ 0.05 were considered significant.

Results: Colorectal cancer patients with ages between $25-50$ years were significantly $(p \leq 0.01)$ higher than the patients with $>50$ years or $<25$ years. Male patients $(57.9 \%)$ were significantly $(p \leq 0.01)$ higher than female patients $(42.1 \%)$. The rate of patients with family history was $39.4 \%$ of the total patients. Diabetic and smoking patients presented $28.7 \%$ and $37.9 \%$, respectively. Patients with serum CEA $>5 \mathrm{ng} / \mathrm{mL}$ presented the high percentage $(83.6 \%)$ and they were highly significant $(p \leq 0.001)$ than patients with serum CEA less than 5. Stage $2(48.2 \%)$ was significantly $(p \leq 0.01)$ higher than stage $1(16.6 \%), 3(20.6 \%)$ and 4 $(14.5 \%)$, respectively. For bowl habit, constipation presented $75.8 \%$ was significantly higher than diarrhea $(14.5 \%)$. In addition, symptoms of bleeding per rectum $(71.1 \%)$ were significantly higher than symptoms of pain $(28.2 \%)$.

Conclusion: Colorectal cancer is significant disease in Iraq. Middle age patients presented the highest percentage. Education of patients about bowl habit and symptoms of colorectal cancer should be applied especially constipation and bleeding per rectum.

Keywords: Colorectal cancer, serum carcinoembryonic antigen, stages of cancer, bowl habit.

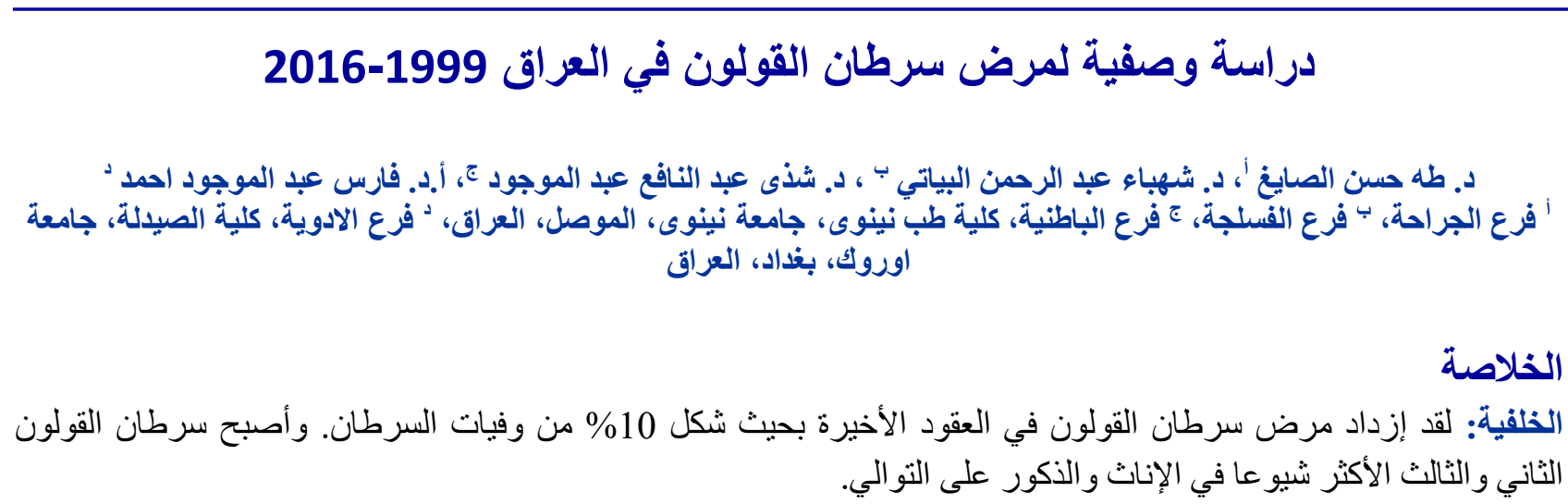




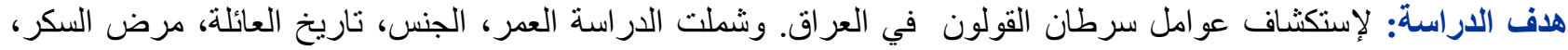

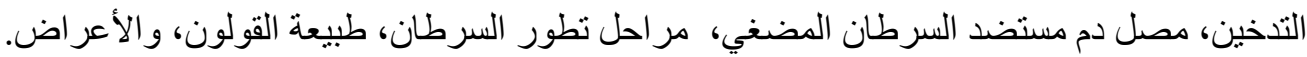

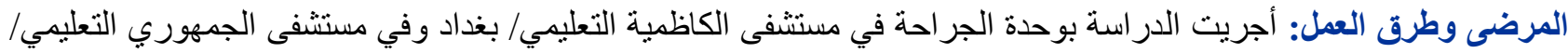
الموصل للفترة من شباط 1999- حزيران 2016 ـ وكانت دراسة سلسلة حالات على 956 مريض بسرطان القولون. وشملت

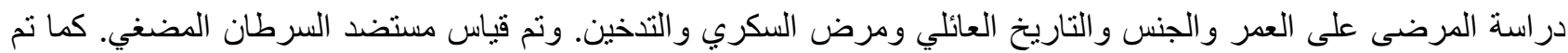
در اسة مر احل السرطان، طبيعة القولون، وأعر اض المرض. وقالع وقدمت النتائج بالمعدل و النسبة المئوية وحلات إحصائيا بإستعمال

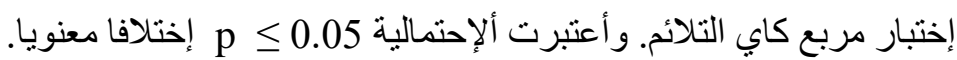

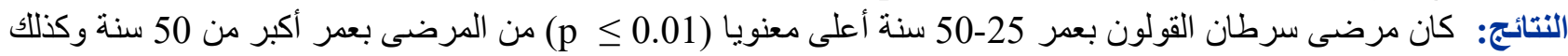

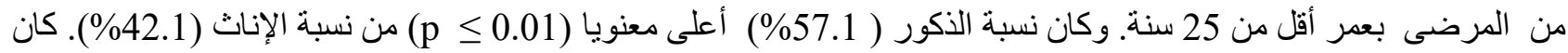

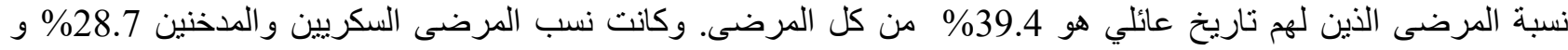

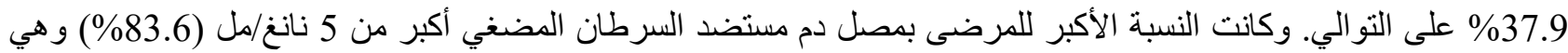

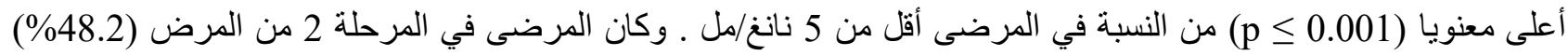

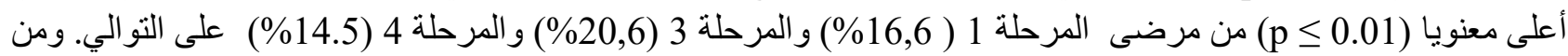
طبيعة القولون كان المرضى المصابين بالإمساك هو

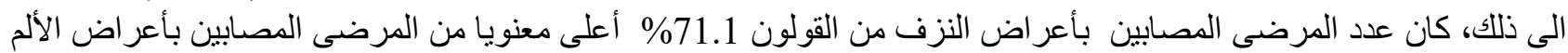

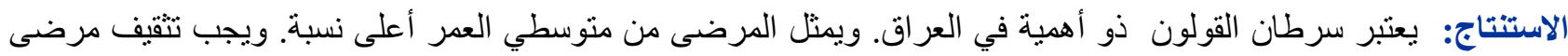

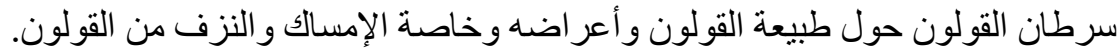

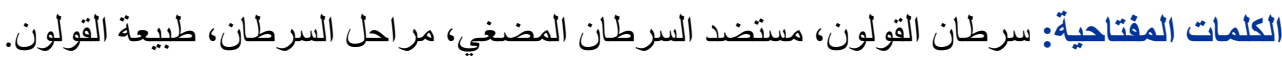

\section{INTRODUCTION}

$\mathrm{n}$ western countries, colorectal cancer has increased in the last decades which accounts about $10 \%$ of cancer mortality. ${ }^{1}$ It becomes the second and third most common cancer in women and men respectively. ${ }^{2}$ In developed countries, colorectal cancer has also increased, the reason of increased mortality of colorectal cancer was attributed to population aging, dietary habit, smoking, low physical activity, and obesity. ${ }^{1}$

In Iraq, several descriptive studies were conducted in colorectal cancer, the colorectal cancer was low but has increased in the last few years. ${ }^{3}$ The descriptive Iraqi studies of colorectal cancer included age, gender, signs, and symptoms. ${ }^{4,5}$

Carcinoembryonic antigen (CEA) is the most commonly tumor marker for colorectal cancer and the concentration in tumors is much higher than nonmalignant tissues. ${ }^{6}$ Serum CEA was still the best tumor marker as independent prognostic factor for colorectal cancer. ${ }^{7}$ The level of serum CEA predicts under-staging and the possibility of recurrence. ${ }^{8}$

This work was conducted in order to give a descriptive study for colorectal cancer patients regarding age, gender, family history, smoking and diabetes and serum CEA, stages of cancer, bowl habit, and symptoms.

\section{PATIENTS AND METHODS}

The study was conducted in Alkathymia Teaching Hospital, Baghdad and in Al-Jammhory Teaching Hospital, Mosul during the period from Feb-1999 to June-2016. This is a case series study for 956 patients with colorectal cancer. The data collected included: age, gender and family history. Other factors for the patients were also studied including diabetes and smoking. The study included smokers with 15 to 20 cigarettes per day for more than 5 years. Serum CEA was measured as a predictor factor for the diagnosis and severity of the disease. Stages of the disease, bowl habit and symptoms were also evaluated. The estimation of serum CEA based on fluorescence immunoassay technology using sandwich immune assay. ${ }^{9}$

Data are presented as percentages, and were analyzed by using Chi square test goodness of fit. $p$ values $\leq 0.05$ were considered significant. 
Statistical analysis was performed by using SPSS package version 16 .

\section{RESULTS}

Table 1 shows that patient ages were between 2550 years were the higher proportion of patients and were significantly $(p \leq 0.01)$ higher than the other patients with $\geq 50$ years or $\leq 25$ years. Male patients $(57.9 \%)$ were significantly $(p \leq 0.01)$ higher than female patients $(42.1 \%)$. Patients with family history were $39.4 \%$ of the total patients. Diabetic and smoking patients presented $28.7 \%$ and $37.9 \%$, respectively. Most of the patients had serum CEA $\geq 5 \mathrm{ng} / \mathrm{mL}(83.6 \%)$ and they were highly significant $(p \leq 0.001)$ than patients with serum CEA less than 5 . Stage $2(48.2 \%)$ was significantly higher than stage $1(16.6 \%), 3$ (20.6\%) and 4 (14.5\%).

For bowl habit, constipation presented $75.8 \%$ was significantly higher than diarrhea (14.5\%). In addition, symptoms of bleeding per rectum $(71.1 \%)$ was significantly higher than symptoms of pain was $28.2 \%$.

Table 1. Descriptive study of colorectal cancer in Iraq (No.=956).

\begin{tabular}{|c|c|c|}
\hline Parameters & Frequency (\%) & $p$ values \\
\hline \multicolumn{2}{|l|}{ Age (years) } & \multirow{4}{*}{$\begin{array}{l}\text { Different letters } \\
\text { mean significant } \\
\text { at } p \text { value } \leq 0.01\end{array}$} \\
\hline$\leq 25$ & $173(18.1 \%)^{\mathrm{a}}$ & \\
\hline$>25-50 \leq$ & $436(45.6 \%)^{b}$ & \\
\hline$>50$ & $347(36.3)^{c}$ & \\
\hline \multicolumn{3}{|l|}{ Gender } \\
\hline Male & 546 (57.1\%) & \multirow{2}{*}{$\leq 0.001$} \\
\hline Female & 410 (42.9\%) & \\
\hline \multicolumn{3}{|l|}{ Family history } \\
\hline Yes & 377 (39.4\%) & \multirow{2}{*}{$\leq 0.001$} \\
\hline No & $579(60.6 \%)$ & \\
\hline \multicolumn{3}{|l|}{ Diabetes } \\
\hline Yes & $274(28.7)$ & \multirow{2}{*}{$\leq 0.001$} \\
\hline No & $682(71.3)$ & \\
\hline \multicolumn{3}{|l|}{ Smoking } \\
\hline Yes & $362(37.9)$ & \multirow{2}{*}{$\leq 0.001$} \\
\hline No & $594(62.1)$ & \\
\hline \multicolumn{3}{|l|}{ CEA (ng/mL) } \\
\hline$<5$ & 157 (16.4\%) & \multirow{2}{*}{$\leq 0.001$} \\
\hline$\geq 5$ & 799 (83.6\%) & \\
\hline \multicolumn{3}{|l|}{ Stages } \\
\hline 1 & $159(16.6 \%)^{\mathrm{a}}$ & \multirow{4}{*}{$\begin{array}{l}\text { Different letters } \\
\text { mean significant } \\
\text { at } p \text { value } \leq 0.01\end{array}$} \\
\hline 2 & $461(48.2 \%)^{b}$ & \\
\hline 3 & $197(20.6 \%)^{a, c}$ & \\
\hline 4 & $139(14.5 \%)^{a, d}$ & \\
\hline \multicolumn{3}{|l|}{ Bowl habit } \\
\hline Constipation & $725(75.8 \%)^{*}$ & $\leq 0.001$ \\
\hline
\end{tabular}

\begin{tabular}{lll}
\hline Diarrhea & $139(14.5 \%)$ & \\
Symptoms & & \\
Bleeding per rectum & $680(71.1 \%)^{*}$ & $\leq 0.001$ \\
Pain & $270(28.2 \%)$ & \\
\hline
\end{tabular}

\section{DISCUSSION}

In the present study, colorectal cancer patients with ages range between 25-50 years were significantly higher than patients with more than 50 year old or less than 25 year old. These result are inconsistent with published litrtures. ${ }^{10,11}$ However, colorectal cancer patients under 50 years were about the same as patients with above 50 years old, supporting that colorectal cancer was increasing in adult under the age 50 years. ${ }^{12}$ The reason of high percentage of the patients for the range 25-50 years old in this study could be attributed to shorter life span where elderly represent small proportion of Iraqi population pyramid.

In this work, male patients were significantly higher than female patients. These results are in agreement with previously published series from in USA, ${ }^{13}$ and Japan. ${ }^{14}$ Estrogen plays an important role for the protection of colorectal cancer through ER $\beta$ that has anti-proliferation and apoptosis. ${ }^{15}$ Accordingly, female had better survival than male which made the gender a significant factor for colorectal cancer survival. ${ }^{16}$

About $40 \%$ the patients had family history which is considered high enough to be taken into this study. Many studies were also relevant with this result. ${ }^{17}$ Obuch et al ${ }^{18}$ found that mutation of DNA was the cause of colorectal cancer. The family history factor had a role of approximately $15 \%$ $20 \%$ of incidence of colorectal cancer in patients. ${ }^{1}$ In addition, the risk of colorectal cancer is about two times higher for people who have more than one such relative compared with those with one relative. ${ }^{19,20}$

Smokers presented $37.9 \%$ of the studied patients, this percentage should be taken into consideration. Since the association of smoking and colorectal cancer was documented, ${ }^{21}$ and the existence between smoking and the prognosis of non-metastasis colorectal cancer was observed. ${ }^{22}$ The duration and amount of smoking was associated with elevated risk of colorectal cancer. ${ }^{23}$ Cigarette smoking has been shown to facilitate tumor growth by induction of 
angiogenesis and/or suppression of cell-mediated immunity. ${ }^{24}$

In this study, diabetics presented $28.7 \%$ of the colorectal cancer patients. Since this study was a descriptive study the results cannot give any connection between diabetes and colorectal cancer, though the percentage of diabetes in this study should be taken for further study. Controversial studies were found of the connection of diabetes and colorectal cancer. No statistical association between Diabetes and adenomatous polyps. ${ }^{25}$ In addition, the risk of colon cancer recurrence appears to be similar in patients with and without diabetes at diagnosis. ${ }^{26}$ However, poor glycemic control in type 2 diabetic patients was associated with aggressive colorectal cancer. ${ }^{27}$

In the present study, CEA presented $83.6 \%$ for patients of equal or more than $5 \mathrm{ng} / \mathrm{mL}$. The cutoff value was considered $5 \mathrm{ng} / \mathrm{mL}^{28}$ Serum from individuals with colorectal carcinoma often has higher levels of CEA than healthy individuals. ${ }^{29}$ Serum CEA can be used as tumor marker for the diagnosis of colorectal cancer. ${ }^{14}$ However, serum CEA was with slightly elevated value with no specific pathology leading to unnecessary examination and stress to the individual. ${ }^{30}$ Accordingly, serum CEA is not an independent marker for colorectal cancer.

Stages at diagnosis is the most important prognostic factor, five year survival of patients diagnosed with colorectal cancer was $90 \%$ for patients with localized disease, $69 \%$ for patients with regional spread, and below $12 \%$ for patients with metastatic disease. ${ }^{31}$ In the present study, regional spread (stage 2) was the highest rate compared with other stages. The explanation of these results could be the symptoms appeared at the second stage.

Constipation was the most common change in bowl habit, while pain and bleeding per rectum were the most common symptoms. The current results are consistent with other workers who concluded delay diagnosis and hospitalization of half of the colorectal patients. ${ }^{32}$

In conclusion, colorectal cancer has increased in Iraq. Patients with middle ages presented the highest percentage. Education should be applied for colorectal patients about bowl habit and symptoms including constipation and bleeding per rectum.

\section{ACKNOWLEDGEMENT}

This work was supported by Nineveh College of Medicine, University of Nineveh.

\section{REFERENCE}

1. Kuipers EJ, Grady WM, Lieberman D, et al. Colorectal cancer. Nat Rev Dis Primers 2015; 1: 15065.

2. Survival and mortality for colorectal cancer. In Health at a Glance 2015: OECD Indicators, OECD Publishing, Paris. DOI: https://doi.org/10.1787/health_glance-201555-en.

3. Al Dahhan SA, Al Lami FH. Epidemiology of Colorectal Cancer in Iraq, 2002-2014. Gulf J Oncolog 2018; 1(26): 23-6.

4. Al-Bayati SM, Jasim F. Colorectal cancer in a group of Iraqi patients. MMJ 2009; 8(1): 36-9.

5. Al-Janabi AAS, Naseer ZH, Hamody TA. Epidemiological study of cancers in Iraq-Karbala 20082015. Int J Med Res Health Sci 2017; 6(1): 79-86.

6. Duffy MJ. Carcinoembryonic antigen as a marker for colorectal cancer: is clinically useful. Clin Chem 2001; 47(4): 624-30.

7. Wang RF, Song BR, Peng JJ, et al. The Prognostic Value of Preoperative Serum CEA and CA19-9 Values in Stage I-III Colorectal Cancer. Hepatogastroenterology 2014; 61(132): 994-9.

8. Wiratkapun S, Kraemer M, Seow-Choen F, et al. High preoperative serum carcinoembryonic antigen predicts metastatic recurrence in potentially curative colonic cancer: results of a five-year study. Dis Colon Rectum 2001; 44(2): 231-5.

9. Liu M, Jia C, Jin Q, et al. Novel colorimetric enzyme immunoassay for the detection of carcinoembryonic antigen. Talanta 2010; 81(4-5): 1625-9.

10. Neagoe A, Molnar AM, Acalovaschi M, et al. Risk factor of colorectal cancer: an epidemiologic descriptive study of a series of 333 patients. Rom J Gastroenterol. 2004; 13(3): 187-93.

11. Steele SR, Park GE, Johnson EK, et al. The impact of age on colorectal cancer incidence, treatment, and outcomes in an equal-access health care system. Dis Colon Rectum 2014: 57(3): 303-10.

12. Chen FW, Sundaram V, Chew TA, et al. Advanced stage colorectal cancer in persons younger than 50 years not associated with longer duration of symptoms or time to diagnosis. Clin Gastroenterol Hepatol 2017; 15(5): 728-37.

13. Rim SH, Seeff L, Ahmed F, et al. Colorectal cancer incidence in the United States, 1999-2004: an updated analysis of data from the National Program of Cancer Registries and the Surveillance, Epidemiology, and End Results Program. Cancer. 2009; 115(9): 1967-76.

14. Kotake K, Asano M, Ozawa H, et al. Gender differences in colorectal cancer survival in Japan. Int $\mathrm{J}$ Clin Oncol. 2016; 21(1): 194-203.

15. Kim HM, Kim HS. Gender-specific colorectal cancer: epidemiologic difference and role of estrogen. Korean $\mathrm{J}$ Gastroenterol. 2014; 63(4): 201-8. 
16. Yang Y, Wang G, He J, et al. Gender differences in colorectal cancer survival: A meta-analysis. Int J Cancer. 2017; 141(10): 1942-9.

17. Beebe-Dimmer JL, Yee C, Paskett E, et al. Family history of prostate and colorectal cancer and risk of colorectal cancer in the Women's health initiative. BMC Cancer. 2017; 17(1): 848.

18. Obuch JC, Ahnen DJ. Colorectal cancer: genetics is changing everything. Gastroenterol Clin North Am. 2016; 45(3):459-76.

19. Baglietto L, Jenkins MA, Severi G, et al. Measures of familial aggregation depend on definition of family history: meta-analysis for colorectal cancer. J Clin Epidemiol. 2006; 59(2): 114-24.

20. Butterworth AS, Higgins JP, Pharoah P. Relative and absolute risk of colorectal cancer for individuals with a family history: a meta-analysis. Eur J Cancer. 2006; 42(2): 216-27.

21. Liang PS, Chen TY, Giovannucci E. Cigarette smoking and colorectal cancer incidence and mortality: systematic review and meta-analysis. Int $\mathrm{J}$ Cancer. 2009; 124(10): 2406-15.

22. Walter V, Jansen L, Hoffmeister M, et al. Smoking and survival of colorectal cancer patients: population-based study from Germany. Int $J$ Cancer. 2015; 137(6): 1433-45.

23. Lee $\mathrm{S}$, Woo $\mathrm{H}$, Lee J, et al. Cigarette smoking, alcohol consumption, and risk of colorectal cancer in South Korea: A case-control study. Alcohol. 2018; 76: 15-21.

24. O'Byrne KJ, Dalgleish AG, Browning MJ, et al. The relationship between angiogenesis and the immune response in carcinogenesis and the progression of malignant disease. Eur J Cancer 2000; 36(2): 151-69.

25. Budzynska K, Passerman D, White-Perkins D, et al. Diabetes mellitus and hyperglycemia control on the risk of colorectal adenomatous polyps: a retrospective cohort study. BMC Fam Pract. 2018; 19(1):145.
26. Chubak J, Yu O, Ziebell RA, et al. Risk of colon cancer recurrence in relation to diabetes. Cancer Causes Control. 2018; 29(11): 1093-103.

27. Siddiqui AA, Spechler SJ, Huerta S, et al. Elevated $\mathrm{HbA} 1 \mathrm{c}$ is an independent predictor of aggressive clinical behavior in patients with colorectal cancer: a casecontrol study. Dig Dis Sci. 2008; 53(9): 2486-94.

28. Siato et al. Monitoring of serum carcinoembryonic antigen levels after curative resection of colon cancer: cutoff values determined according to preoperative levels enhance the diagnostic accuracy for recurrence. Oncology. 2017;92(5):276-282.

29. Kones RH. CEA: is of value in colorectal cancer? R I Med 1995; 78(6): 164-6.

30. Eleftheriadis N, Papaloukas C, Pistevou-Gompaki K.. Diagnostic value of serum tumor markers in asymptomatic individuals. J BUON. 2009; 14(4): 707-10. 31. Siegel R, Desantis C, Jemal A. Colorectal cancer statistics, 2014.CA Cancer J Clin. 2014; 64(2): 104-17. 32. Jiang $X$, Wang $Y$, Wang $H$, et al. Typical symptoms of colorectal cancer and its influence in timely diagnosis. Zhonghua Yi Xue Za Zhi. 2013; 93(4): 275-9. 